\title{
Conservation Value of Remnant Forest Patches: Tree Composition, Spatial Patterns, and Recruitment in the Ottoville Lowland Forest, American Samoa $^{1}$
}

\author{
Foshua O. Seamon, ${ }^{2}$ Sheri S. Mann, ${ }^{3,4}$ Orlo C. Steele, ${ }^{3,5}$ and Ruth C. B. Utzurrum ${ }^{2}$
}

\begin{abstract}
Native forests increasingly have been reduced to remnant fragments on many Pacific islands. Island and continental ecosystems differ in a number of ways that may increase conservation value of such forest fragments on islands. However, few studies have examined performance of tree populations in Polynesian forest fragments. We tested potential conservation value of the largest contiguous patch of lowland lava flow forest on Tutuila, American Samoa, by determining uniqueness, potential vulnerability, and possible viability of the tree community therein. We recorded 1,186 trees $\geq 10 \mathrm{~cm}$ dbh (diameter at breast height) from 37 species in 12 transects (each $10 \mathrm{~m}$ wide) running from edge to edge across the forest, as well as 1,332 seedlings and 991 saplings within 62 miniplots (each $25 \mathrm{~m}^{2}$ ). Locations within the forest of all 462 trees $\geq 30 \mathrm{~cm}$ $\mathrm{dbh}$, of the 10 most dominant species, were then plotted. The most dominant tree species was Pometia pinnata. Similarity indices between the study site and other protected forests on Tutuila were very low. Spatial distributions and abundances of adult trees, as well as the dispersed distribution of seedlings and saplings, suggested low vulnerability to spatially discrete disturbances. We found evidence of potential edge effects in seedling distributions of two species. Abundances of seedlings and saplings indicated a high potential for continued recruitment of characteristic tree species. Species composition of these recruits is largely composed of characteristic primary forest species rather than secondary forest or invasive species. These results show that even very small forest fragments may have substantial value for conservation, because they can combine high within-island uniqueness with a relatively high likelihood of persistence if left undisturbed.
\end{abstract}

1 This research was supported by Federal Aid in Wildlife Restoration Program funds to the American Samoa Government, and by the Division of Forestry, American Samoa Community College Land Grant Program. Manuscript accepted 19 August 2005.

${ }^{2}$ Department of Marine and Wildlife Resources, American Samoa Government, P.O. Box 3730, Pago Pago, American Samoa 96799 (phone: 684-633-4456; fax: 684-633-5944; e-mail: Joshua.O.Seamon@alum.bu .edu).

\footnotetext{
${ }^{3}$ American Samoa Community College, Land Grant Program, P.O. Box 5319, Pago Pago, American Samoa 96799.

${ }^{4}$ Current address: Division of Forestry and Wildlife, Department of Land and Natural Resources, State of Hawai'i, 1151 Punchbowl Street, Honolulu, Hawai'i 96813.

${ }^{5}$ Current address: Department of Botany, University of Hawai'i at Mānoa, 3190 Maile Way, Honolulu, Hawai'i 96822.
}

Pacific Science (2006), vol. 60, no. 3:319-332

(C) 2006 by University of Hawai'i Press

All rights reserved 
Human activities and attendant habitat fragmentation may have substantial negative effects on forested habitats (e.g., Lovejoy et al. 1983, Burkey 1995, Benítez-Malvido and Martínez-Ramos 2003). Especially in the smaller land masses of the Pacific, forest fragments are often tiny remnants of habitat. In theory, such small fragments may have substantial conservation value (e.g., Turner and Corlett 1996, Rudd et al. 2002, Teo et al. 2003). This value, however, depends on the long-term stability of the remnant forest patches. Herein we examine the justifications for conservation, and potential viability, of one such remnant forest.

The Ottoville Lowland Forest (OLF) is a fragment (ca. 12 ha) of the "Tava-Mamala Forest" (Whistler 1980) that once covered the Tafuna Plain of Tutuila Island, American Samoa. The OLF has long been thought of as unique, both because it occupies areas of largely uneroded volcanic rubble (Amerson et al. 1982b) and because of the presence of very rare tree species such as Dendrocnide harveyi (Seem.) Chew (Amerson et al. 1982a). For that reason, efforts to survey and preserve the area were initiated more than a decade ago, based on botanical, cultural, and zoological grounds (Trail 1993, Whistler 1993).

One prerequisite of a conservation effort is an assessment of the tree species composition in the forest. Whistler (1993) documented the plant species composition of the OLF and recommended its preservation. That survey was conducted in the aftermath of substantial disturbance caused by hurricanes Ofa (in 1990) and Val (in 1991); because of the short time interval between that survey and ours, it is likely that the tree species inventory remains valid today. For this reason, we saw no need to document the species composition of the area.

A second prerequisite is a demonstration that the area actually represents a unique habitat type. This is especially true in a country with limited land area, such as American Samoa, where about $16 \%$ of the land is already protected in the National Park of American Samoa. However, the terrestrial portion of the Tutuila unit of the national park is primarily lowland forest that occurs on hills
(Webb et al. 1999) rather than the generally flat substrate that characterizes the OLF. To compare the OLF with other forests on $\mathrm{Tu}$ tuila, we used species occurrence and size data to determine the structure and species composition of trees within the OLF. We then compared these data between the OLF and four Long-Term Monitoring Plots (Webb and Fa'aumu 1999).

A third prerequisite is determining whether protecting a habitat patch is sufficient to preserve the existing assemblage of plant species and to ensure the survival of characteristic tree species. This is a particular concern with a single small patch, in which species may be vulnerable to many factors (e.g., Lovejoy et al. 1986, Leigh et al. 1993, Mangel and Tier 1994). Because it was impractical to address all possible threats in a single study, we focused on two that seemed the most probable:

(1) First-order (direct) threats: hurricanes and diseases. The forests of American Samoa are subject to frequent natural disturbances, both from hurricanes and tropical storms (Mueller-Dombois and Fosberg 1998) and from virulent fungal pathogens (Brooks 2002). The spatial distribution of a tree species affects its vulnerability to such threats, because hurricane damage is not uniformly distributed across space (Elmqvist et al. 1994) and fungal infection occurs from root-to-root contact (Brooks 2002). A tree species with a spatially restricted or clumped distribution may be catastrophically affected by a swath of hurricane damage or a local fungal outbreak. To assess the potential vulnerability of the OLF to these threats, we determined the spatial distribution of all large trees in the OLF.

(2) Second-order (indirect) threats: isolation and small size. The OLF is a relatively isolated patch of forest, and its small size increases the proportion of the forest that is subject to edge effects and disturbance. Such processes can have many important effects on forest fragments (Laurance and Bierregaard 1997). Direct or indirect reductions in seedling recruitment could leave a relict population of adult trees with no replacements if the patch becomes dominated by 
secondary forest species (Benítez-Malvido and Martínez-Ramos 2003). We determined abundances of seedlings and saplings in the OLF to assess the potential recruits available to sustain the existing composition of the forest. We also plotted the distribution of these recruits in the forest, to assess the possibility of edge effects or very localized seedling establishment.

Therefore, the objectives of this study were threefold: (1) to test the uniqueness of the OLF by comparing its species composition with that of four other lowland forest sites on Tutuila; (2) to predict the vulnerability of the dominant tree species in the OLF to possible disturbance at three scales by determining the spatial pattern of canopy trees; (3) to predict the viability of the dominant tree species in the OLF by determining the abundances and spatial pattern of seedlings and saplings.

\section{MATERIALS AND METHODS}

This study was conducted on the island of Tutuila, American Samoa, located at approximately $170^{\circ} 44^{\prime} \mathrm{W}$ and $14^{\circ} 20^{\prime} \mathrm{S}$. We felt it was important to collect spatially explicit data that sampled a substantial fraction of the largest contiguous area of the OLF (Figure 1). We created 12 transects $10 \mathrm{~m}$ wide (with $25 \mathrm{~m}$ between transect centers) along the south edge of the OLF, for a transect sampling area of 3.1 ha $(\sim 20 \%$ of the largest contiguous habitat patch). Each transect ran from the south to the north edge of the forest. Within each transect, the diameter at breast height (dbh), species, and spatial coordinates of all trees $\geq 10 \mathrm{~cm}$ dbh were determined. The multiple, netlike trunks of Ficus prolixa can produce large but possibly inaccurate values for dbh and basal area, and separate trunks from an individual tree often fell both inside and outside the transect area. We calculated the dbh in these cases around each separate trunk that fell within the transects and then summed the values for the individual trunks to create a total value per banyan. This species was omitted from most analyses, due to the high variance in these estimates, its absence from the Long-Term Monitoring
Plots (although it is widespread in ridge forests on Tutuila), and its exclusion from the calculations in Whistler (1993). We also collected dbh, species, and location data for all trees of $\geq 30 \mathrm{~cm}$ dbh that occurred within the OLF but outside the area covered by the transects.

One circular $\left(2.82-\mathrm{m}\right.$ radius; $\left.25 \mathrm{~m}^{2}\right)$ miniplot centered on the midline of the transect was located randomly within each 50-m interval along each transect. All saplings and seedlings were counted and identified within each miniplot. Because of the irregular edges of the forest, we surveyed a total of 62 miniplots. Due to the difficulty of distinguishing Dysoxylum maota Reinecke and D. samoense A. Gray at the seedling stage, data from these two species were combined for some subsequent analyses.

All data were collected in April 2001 by a consistent set of personnel from the American Samoa Government, Department of Marine and Wildlife Resources (DMWR) and the American Samoa Community College, Land Grant. Comparisons with other lowland forests on Tutuila were based on data compiled from four 1.2-ha DMWR Long-Term Monitoring Plots. Some of those Long-Term Monitoring Plot data have been previously published (e.g., Webb and Fa'aumu 1999). Relative dominance, $t$ tests, correlations, summary data analyses, similarity indices (Krebs 1999), and other manipulations of the data sets were conducted using SAS (vers. 8.1, SAS Institute, Cary, North Carolina).

Spatial patterns within each species of large canopy trees $(\geq 30 \mathrm{~cm} \mathrm{dbh})$ were analyzed using SPPA (vers. 1.1.1 [Haase 1995]) software. Statistically significant deviations from a spatially random distribution were determined by comparison of the Ripley's Supremum (K) of the data to the distribution obtained from 999 randomizations of the same location data. This method is less prone to edge effects than other methods (Haase 1995), an important consideration in a study area of this size. We tested for randomness in spatial distributions at several spatial scales, because spatial point patterns are often scale dependent (Dale 1999). First, we 


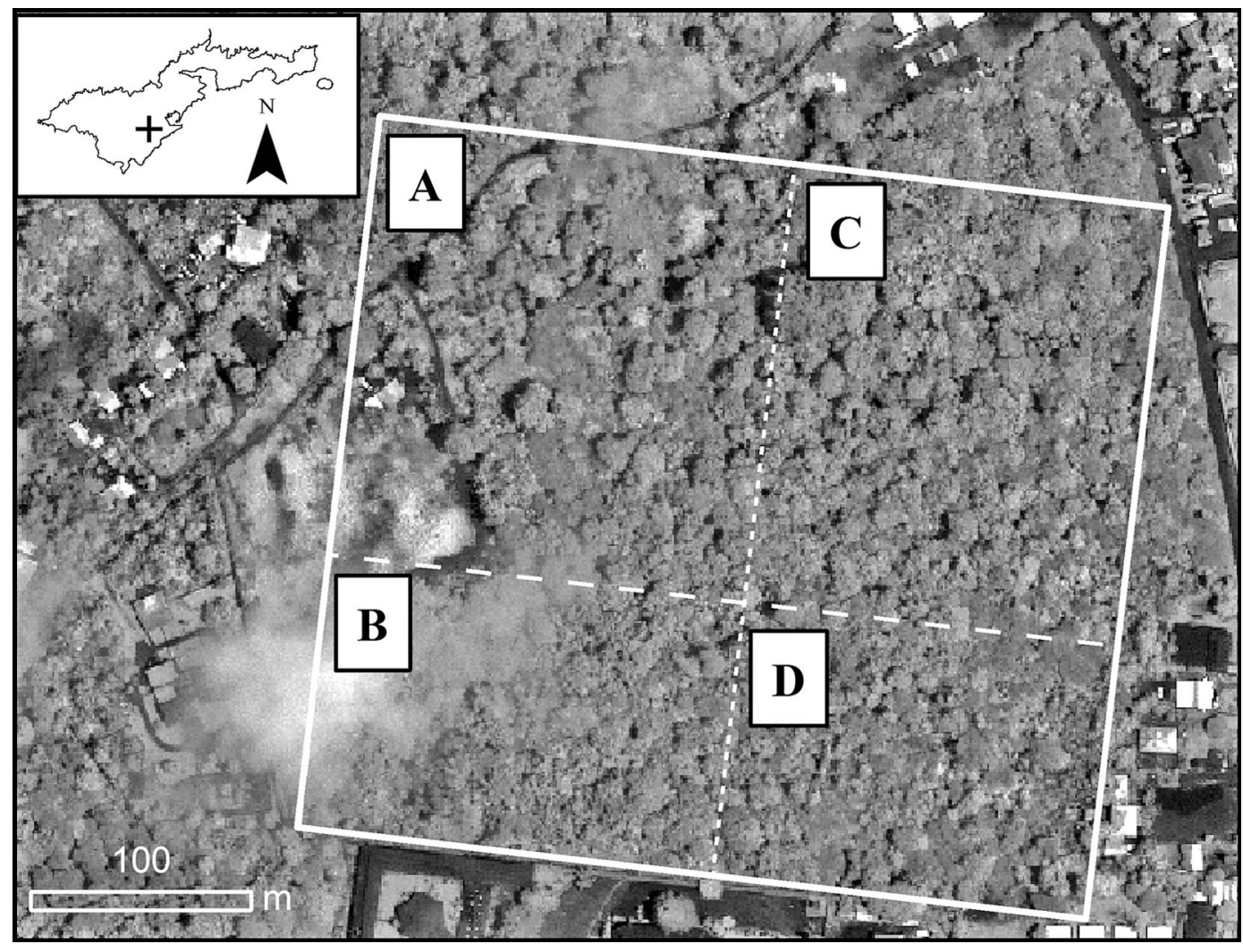

FIgURE 1. Satellite image (IKONOS, Space Imaging Systems, 2001) of the Ottoville Lowland Forest and surrounding area, with an inset showing the location of the image on Tutuila Island, American Samoa. The white rectangles are the areas used in the analyses of spatial pattern in adult trees (Table 4). A (the area enclosed within the largest rectangle, including areas B, C, and D) represents the approximate location of the spatial plots shown in Figure 2. B is the fraction of area A south of the dashed line, $\mathrm{C}$ the fraction east of the dotted line, and $\mathrm{D}$ is the intersection of areas $\mathrm{B}$ and $\mathrm{C}$.

tested for spatial randomness in a rectangular area of the forested area we surveyed (rectangle A in Figure 1; 12.3 ha total). Then we tested distributions within three smaller subsets of the study area, in an attempt to detect spatial heterogeneity at various spatial scales. One of these subsets removed approximately the northern half of the area from the analysis (Figure 1, B; $4.6 \mathrm{ha}$ ), and another removed the western half (Figure 1, C; 7.0 ha). The last was an area of what appeared to be some of the most intact primary forest and included only the intersection of subsets $\mathrm{B}$ and $\mathrm{C}$ (Figure 1, D; 2.1 ha).

We calculated a simple correlation be- tween abundances of seedlings, saplings, and adults with each species as a single datum. We used Spearman's rank correlations because of the potentially large variance in numbers of individuals among different species and excluded species for which no canopy-sized individuals could occur. We also graphically examined the size structure of the population, by plotting the number of individuals per hectare in each size class for each species. Because seedlings and saplings were only sampled in the transects, we did not use spatially explicit SPPA to test their spatial pattern. Instead, we plotted the frequency distributions of seedlings and saplings 
among the miniplots, as well as the proximity of these miniplots to the edges of the OLF. We created six seedling and sapling abundance categories, representing miniplots in which we counted $1-5,6-10,11-15,16-20$, $21-25$, and $>25$ individuals. We also created seven categories reflecting the distance in meters from the forest edge for a given miniplot: $\leq 10,11-20,21-30,31-40,41-50,51-100$, and $>100$.

\section{RESULTS}

We encountered a total of 1,186 individual trees from 37 species in the transects. Ficus prolixa Forst. $(n=3)$ was the most dominant species, in spite of their low numbers, with an estimated relative basal area of $49 \%$. Ignoring $F$. prolixa, the three species with greatest total basal area were Pometia pinnata Forst., Dysoxylum maota, and D. samoense (Table 1). Our rankings differ from those of Whistler (1993) mainly in the increased prevalence of edge species (Macaranga barveyana Muell. Arg. and Pipturus argenteus [Forst. f.] Wedd.) and agroforest species (Mangifera indica L. and Cocos nucifera L.) in our samples. This difference is attributable to differences in sampling protocols (cf. Whistler [1993], who sampled a roughly circular area parallel to the perimeter of the forest), rather than a short-term shift in forest structure. The dbh of trees in the OLF is slightly but significantly greater than in other forests: $t=2.80$, $P<.006$ (ln-transformed with Cochran's correction for unequal variances, $\mu_{\mathrm{OLF}}=22.5$ $\mathrm{cm} \quad[n=1,186], \quad \mu_{\text {LTMP }}=21.4 \mathrm{~cm} \quad[n=$ 2,799]).

We compared the species composition between the OLF and the four Long-Term Monitoring Plots from other locations on Tutuila (Webb and Fa'aumu 1999). We calculated the relative dominance at all five sites (Table 2). Two of the 10 most dominant species in the OLF (Pometia pinnnata and Pisonia umbellifera [Forst.] Seem.) were not found in the Long-Term Monitoring Plots, and two other large forest species (Dysoxylum maota and Elaeocarpus ulianus Christoph.) were not ranked in the top 10 of any Long-Term Monitoring Plot. To test the significance of
TABLE 1

Tree Species Recorded from 12 Transects Covering 23.1 ha of Ottoville Lowland Forest, Ranked by Basal Area (16 Other Species with Relative Dominance $<1 \%$ Are Omitted)

\begin{tabular}{|c|c|c|c|c|}
\hline Species & $n$ & $\begin{array}{c}\text { Relative } \\
\text { Basal } \\
\text { Area (\%) }\end{array}$ & $\begin{array}{l}2001 \\
\text { Rank }\end{array}$ & $\begin{array}{c}1993 \\
\operatorname{Rank}^{a}\end{array}$ \\
\hline Ficus prolixa ${ }^{b}$ & 3 & 49 & - & - \\
\hline Pometia pinnata & 100 & 22 & 1 & 2 \\
\hline Dysoxylum maotac & 181 & 13 & 2 & 1 \\
\hline Dysoxylum samoense ${ }^{c}$ & 74 & 11 & 3 & 3 \\
\hline Cananga odorata & 119 & 9 & 4 & 7 \\
\hline Macaranga barveyana & 218 & 8 & 5 & 12 \\
\hline Planchonella samoensis & 45 & 7 & 6 & 4 \\
\hline Pisonia umbellifera & 88 & 5 & 7 & 5 \\
\hline Elaeocarpus ulianus & 30 & 4 & 8 & 11 \\
\hline Pipturus argenteus & 115 & 4 & 9 & 27 \\
\hline Myristica inutilis & 32 & 2 & 10 & 10 \\
\hline Syzygium samarangense & 11 & 2 & 11 & 9 \\
\hline Macaranga stipulosa & 6 & 1 & 12 & 6 \\
\hline Mangifera indica & 6 & 1 & 13 & - \\
\hline Cocos nucifera & 16 & 1 & 14 & - \\
\hline Dendrocnide harveyi & 6 & 1 & 15 & 12 \\
\hline Ficus godeffroyid & 40 & 1 & 16 & - \\
\hline Alphitonia zizyphoides & 5 & 1 & 17 & 31 \\
\hline Artocarpus altilis & 11 & 1 & 18 & 24 \\
\hline Rhus taitensis & 10 & 1 & 19 & 28 \\
\hline Adenanthera pavonina & 13 & 1 & 20 & 25 \\
\hline
\end{tabular}

a Based on basal area reported in Whistler (1993).

${ }^{b}$ Excluded from calculation of relative basal area for the other species (see Materials and Methods).

${ }^{c}$ Identification was not certain for 11 individual Dysoxylum. Those individuals are omitted from this table, but their exclusion might alter these rankings slightly.

${ }^{d}$ We assigned trees to this species that may have been assigned to F. scabra or F. tinctoria by Whistler (1993), although we also recorded $F$. scabra $(n=3)$ and $F$. tinctoria $(n=10)$.

this apparent difference, we calculated similarity indices (Krebs 1999) for each possible pairwise comparison between the different areas (Table 3). Sorenson's indices did not show clear differences between the species present in the Long-Term Monitoring Plots and the OLF. The single lowest similarity $\left(\mathrm{S}_{\mathrm{s}}=0.35\right)$ was between the OLF and the Vatia Long-Term Monitoring Plot, but two of the next three lowest $S_{s}$ were between Long-Term Monitoring Plots, not a LongTerm Monitoring Plot and the OLF. Thus, based strictly on species occurrences (i.e., $\mathrm{S}_{\mathrm{s}}$ ), there were as many differences between the Long-Term Monitoring Plots as between 
TABLE 2

The Top 10 Tree Species, Ranked by Basal Area, in Five Forested Areas on Tutuila, American Samoa

\begin{tabular}{lllll}
\hline \hline \multicolumn{1}{c}{ OLF } & \multicolumn{1}{c}{ Alava LTMP $^{a}$} & \multicolumn{1}{c}{ Amalau LTMP } & \multicolumn{1}{c}{ Maloata LTMP } & \multicolumn{1}{c}{ Vatia LTMP $^{a}$} \\
\hline Pometia pinnata & Rhus taitensis & Inocarpus fagifer & Canarium vitiense & Canarium vitiense \\
Dysoxylum maota & Adenanthera pavonina & Bischofia javanica & Syzygium inophylloides & Syzygium inophylloides \\
Dysoxylum samoense & Myristica inutilis & Dysoxylum samoense & Calophyllum neo-ebudicum & Myristica inutilis \\
Cananga odorata & Hibiscus tiliaceus & Canarium vitiense & Myristica inutilis & Buchanania merrillii \\
Macaranga barveyana & Neonauclea forsteri & Garuga floribunda & Diospyros samoensis & Calophyllum neo-ebudicum \\
Planchonella samoensis & Canarium vitiense & Neonauclea forsteri & Inocarpus fagifer & Myristica hypargyraea \\
Pisonia umbellifera ${ }^{b}$ & Buchanania merrillii & Canarium barveyi & Rbus taitensis & Canarium barveyi \\
Elaeocarpus ulianus & Canarium harveyi & Myristica inutilis & Hibiscus tiliaceus & Diospyros samoensis \\
Pipturus argenteus & Bischofia javanica & Barringtonia asiatica & Neonauclea forsteri & Planchonella samoensis \\
Myristica inutilis & Cananga odorata & Hibiscus tiliaceus & Alphitonia zizyphoides & Neonauclea forsteri \\
\hline
\end{tabular}

Note: All the Long-Term Monitoring Plots (LTMPs) are composed of lowland ridge forest, although the Alava plot is considered a young, relatively recently disturbed area (Webb and Fa'aumu 1999).

${ }^{a}$ Located in the National Park of American Samoa.

${ }^{b}$ No individuals of these species were recorded in the LTMPs.

TABLE 3

Similarity Indices among Pairs of Sites Listed in Table 2 (but Including All Tree Species Present in Each Community)

\begin{tabular}{lccccc}
\hline \hline & OLF & Alava & Amalau & Maloata & Vatia \\
\hline OLF & & 0.53 & 0.65 & 0.55 & 0.35 \\
Alava & 0.13 & & 0.62 & 0.69 & 0.68 \\
Amalau & 0.19 & 0.73 & & 0.65 & 0.53 \\
Maloata & 0.12 & 0.77 & 0.77 & 0.90 & 0.49 \\
Vatia & 0.13 & 0.66 & 0.72 & 0.90 & \\
\hline
\end{tabular}

Note: Sorenson's Index $\left(\mathrm{S}_{\mathrm{S}}\right.$, above the diagonal) reflects simple presence/absence of species, whereas Morisita's Index $\left(\mathrm{C}_{2}\right.$ below the diagonal) incorporates the relative abundances of the constituent species in each community. A higher number indicates increasing similarity.

the Long-Term Monitoring Plots and the OLF. Morisita's $\mathrm{C}_{\lambda}$, which incorporates relative abundance, showed significant differences between the OLF and the Long-Term Monitoring Plots: all four of the least-similar pairwise comparisons involve the OLF, and all were much lower than the similarity indices between pairs of Long-Term Monitoring Plots (Table 3).

Spatial patterns in eight of the 10 most common tree species of the OLF were significantly clumped at the largest scale we tested (area A in Figure 1; column A in Table 4; the entire area within an individual plot in Figure
2). This may be attributable to a disturbed area in the northwest corner of the forest, visible in Figure 1 and reflected in the open space above and to the west of a northwest diagonal in most of the panels in Figure 2, which perforce causes clumping of the tree distributions at this scale of analysis. Only Myristica inutilis (Rich ex A. Gray) Sinclair and Syzygium samarangense ([Bl.] Merr. \& Perry) were randomly distributed at this scale.

The three most dominant tree species (Pometia pinnata, Dysoxylum maota, and D. samoense) were significantly clumped at intermediate spatial scales (Table 4), although all were widespread within the boundaries of the forest (Figure 2). Conversely, less abundant species such as Pisonia umbellifera and Macaranga harveyana were randomly distributed (Table 4). Both Cananga odorata (Lam.) Hook f. \& Thoms. and Elaeocarpus ulianus were randomly distributed in some areas of the forest (e.g., subset B) but not in others (e.g., subset C) (Table 4, Figure 1).

At the smallest scale we tested (area D in Figure 1) the sample sizes of some species were quite small, but five species had more than 10 individuals. Four of these five species were randomly distributed (Table 4). The exception is Pometia pinnata, which is not randomly distributed at any scale we analyzed (Table 4). 


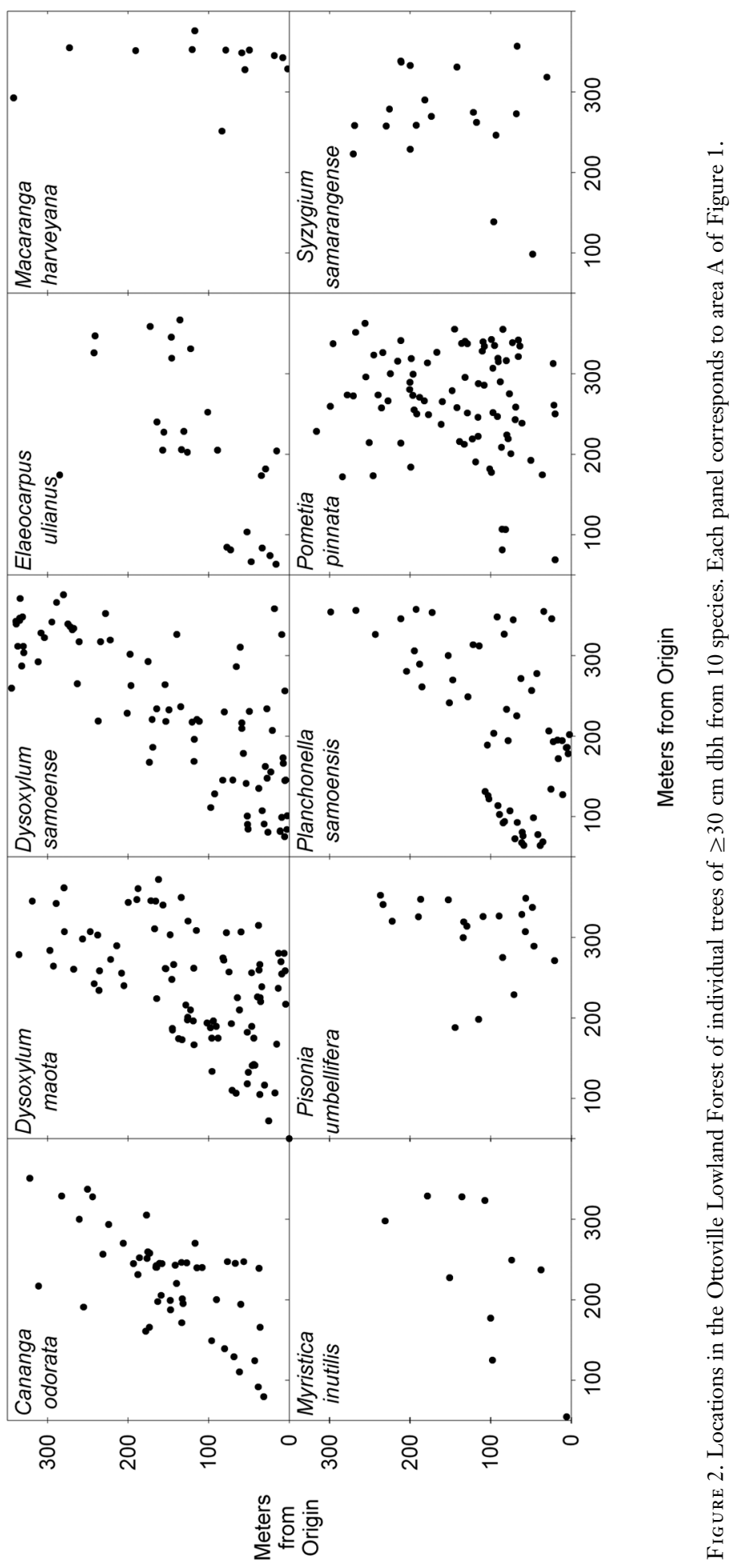


TABLE 4

Tests for Spatial Randomness of the Dominant Tree Species in the Ottoville Lowland Forest Based on Trees $\geq 30 \mathrm{~cm} \mathrm{dbh}$

\begin{tabular}{|c|c|c|c|c|}
\hline Species & $\begin{array}{c}\mathrm{A} \\
(\sim 12 \mathrm{ha})\end{array}$ & $\begin{array}{c}\mathrm{B} \\
(\sim 5 \mathrm{ha})\end{array}$ & $\begin{array}{c}\text { C } \\
(\sim 7 \mathrm{ha})\end{array}$ & $\begin{array}{c}\mathrm{D} \\
(\sim 2 \mathrm{ha})\end{array}$ \\
\hline Pometia pinnata & $(87)^{* *}$ & $(44)^{* *}$ & $(75)^{\star *}$ & $(35)^{\star *}$ \\
\hline $\begin{array}{l}\text { Dysoxylum } \\
\text { maota }\end{array}$ & $(92)^{\star *}$ & $(55)^{\star *}$ & $(61)^{\star *}$ & (28)ns \\
\hline $\begin{array}{l}\text { Dysoxylum } \\
\text { samoense }\end{array}$ & $(83)^{* *}$ & $(42)^{* *}$ & $(53)^{* *}$ & (14)ns \\
\hline $\begin{array}{l}\text { Cananga } \\
\text { odorata }\end{array}$ & $(52)^{* *}$ & $(18) \mathrm{ns}$ & $(34)^{* *}$ & (8)ns \\
\hline $\begin{array}{l}\text { Macaranga } \\
\text { barveyana }\end{array}$ & $(13)^{* *}$ & (10)ns & (13)ns & (9)ns \\
\hline $\begin{array}{l}\text { Planchonella } \\
\text { samoensis }\end{array}$ & $(58)^{\star * *}$ & $(45)^{* *}$ & (29)ns & (16)ns \\
\hline $\begin{array}{l}\text { Pisonia } \\
\quad \text { umbellifera }\end{array}$ & $(21)^{* *}$ & (12)ns & (19)ns & (11)ns \\
\hline $\begin{array}{l}\text { Elaeocarpus } \\
\text { ulianus }\end{array}$ & $(26)^{* *}$ & (14)ns & $(16)^{* *}$ & (5)ns \\
\hline $\begin{array}{c}\text { Myristica } \\
\text { inutilis }\end{array}$ & (10)ns & $(6) n s$ & (7)ns & (3)ns \\
\hline $\begin{array}{l}\text { Syzygium } \\
\text { samarangense }\end{array}$ & (20)ns & $(8) \mathrm{ns}$ & $(18) \mathrm{ns}$ & (6)ns \\
\hline $\begin{array}{l}\text { Ten dominant } \\
\text { species } \\
\text { combined }\end{array}$ & $(462)^{* *}$ & $(254)^{* *}$ & $(325)^{\star \star}$ & $(135)++$ \\
\hline
\end{tabular}

Note: Pipturus argenteus is omitted because it has very few individuals in this size class. It is replaced by Syzygium samarangense. Each column represents tests only of those trees occurring within the corresponding subset (area A, B, C, or D from Figure 1) of the study area. The number of individuals is given in parentheses in each case.

**, Significantly clumped spatial distribution based on Ripley's Supremum; ns, random distribution; ++ , significantly overdispersed (regular) spatial distribution.

We also combined the dominant tree species for spatial analysis. At the three largest scales we found significant clumping of stems (Table 4). Conversely, trees at the most local scale were significantly overdispersed (i.e., more evenly distributed than expected by chance). Thus, when all species are considered together there is significant spatial heterogeneity within large sections of the OLF. These patterns disappear only at the smallest scales and within the most intact parts of the forest.

We counted a total of 1,322 seedlings from 34 species and 991 saplings from 30 species was counted in the miniplots, in addition to approximately 35 non-tree and ground cover species. Abundances per hectare were significantly correlated (based on Spearman's rank correlations) between the size classes ( $n=37$ species; seedlings versus saplings: $r=0.85, P<.0001$; seedlings versus canopy trees: $r=0.53, P<.0009$; saplings versus canopy trees: $r=0.60, P<.0001)$. However, when we excluded very rare species (i.e., those for which 10 or fewer individuals, regardless of size class, were detected), only the correlation between seedlings and saplings was significant $(n=22, r=0.87, P<.0001)$.

The overall size structure in the OLF provides evidence of a substantial potential for recruitment (Figure 3). Dominant canopy species (Pometia pinnata, the two Dysoxylum species, and Cananga odorata) all exhibited high abundances of both seedlings and saplings, as well as approximately continuous distributions of adult sizes. Pisonia umbellifera, in contrast, had a peak in abundance in the sapling and intermediate size categories. Macaranga barveyana and Pipturus argenteus had substantially fewer (or none, in the case of $P$. argenteus) seedlings than adults (Figure 3 ).

The majority of recruits occurred in low abundances within any particular miniplot (Figure 4). Pometia pinnata and Dysoxylum spp. were characterized by many aggregations of recruits, including some of 25 or more seedlings per miniplot, but this occurred in addition to widespread recruitment in low numbers. Planchonella samoensis H. J. Lam ex Christoph. and Syzygium samarangense occasionally occurred in clusters of 15 or more recruits per miniplot. Both Elaeocarpus ulianus and Pisonia umbellifera had low numbers of seedlings.

There was no clear-cut relationship between sapling recruitment and edges (Figure 4). All species had at least some saplings within $10 \mathrm{~m}$ of the forest edge. Even nominally edge species such as Pipturus argenteus and Macaranga harveyana showed some recruitment of sapling-sized individuals well away from the edges of the OLF, presumably into gaps. The distribution of seedlings was much more heterogeneous. In four species we observed no seedlings fewer than $10 \mathrm{~m}$ from an edge: Elaeocarpus ulianus, P. argenteus, Piso- 


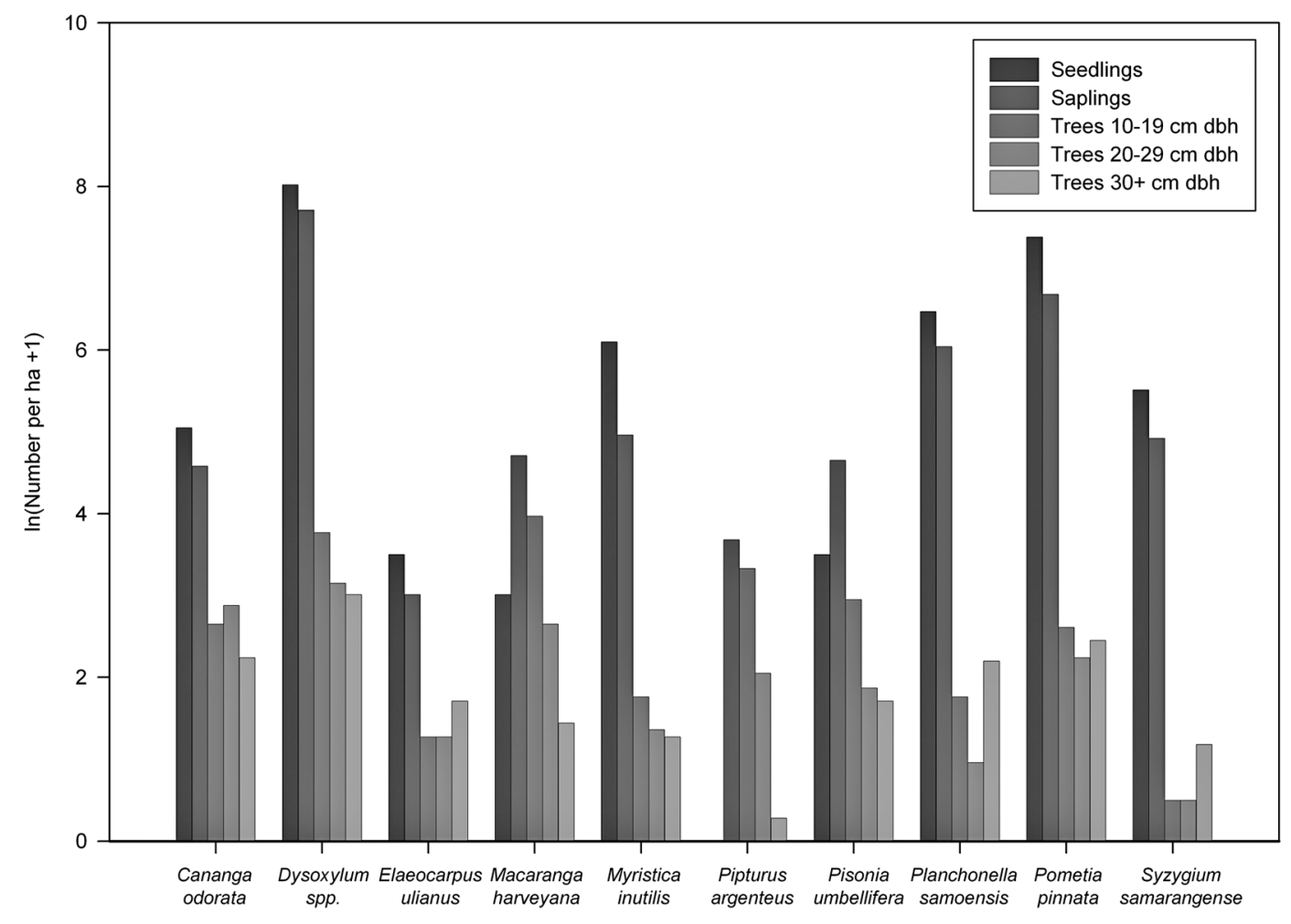

Figure 3. The size-class structure of 10 tree species in the Ottoville Lowland Forest. Dysoxylum spp. includes both D. maota and D. samoense because the seedlings of each species are difficult to distinguish.

nia umbellifera, and Syzygium samarangense. Conversely, both Dysoxylum species and Planchonella samoensis showed no obvious relationship between abundances of seedlings and forest edges. The most dominant species, Pometia pinnata, had spatially widespread recruitment, albeit with the greatest abundances farthest from the forest edge.

There was no consistent relationship between the spatial distributions of adults, seedlings, and saplings. For example, Pometia pinnata adults exhibited a clumped distribution at all scales (Table 4, Figure 2) and yet most miniplots in which it occurred had only one or a few recruits (Figure 4). Conversely, recruits were abundant and occasionally clumped in both Planchonella samoensis (in which large trees were common and randomly distributed at one of three scales) and
Myristica inutilis (in which large trees were rare and randomly distributed at all scales [Figures 2, 3 and Table 4]).

\section{DISCUSSION}

Our results show that the OLF represents a unique component of the vegetation of American Samoa. The composition and structure of the forest are significantly different from those found in other lowland forest sites on Tutuila. It is conceivable, of course, that patches similar to the OLF might occur elsewhere on Tutuila. However, lava flow forests (Whistler 2002) like the OLF typically occur on flat or gently sloping terrain that has a volcanic rubble substrate. Tafuna is essentially the only area of Tutuila with such a substrate that is not characterized by steep 


\section{A. SEEDLINGS}

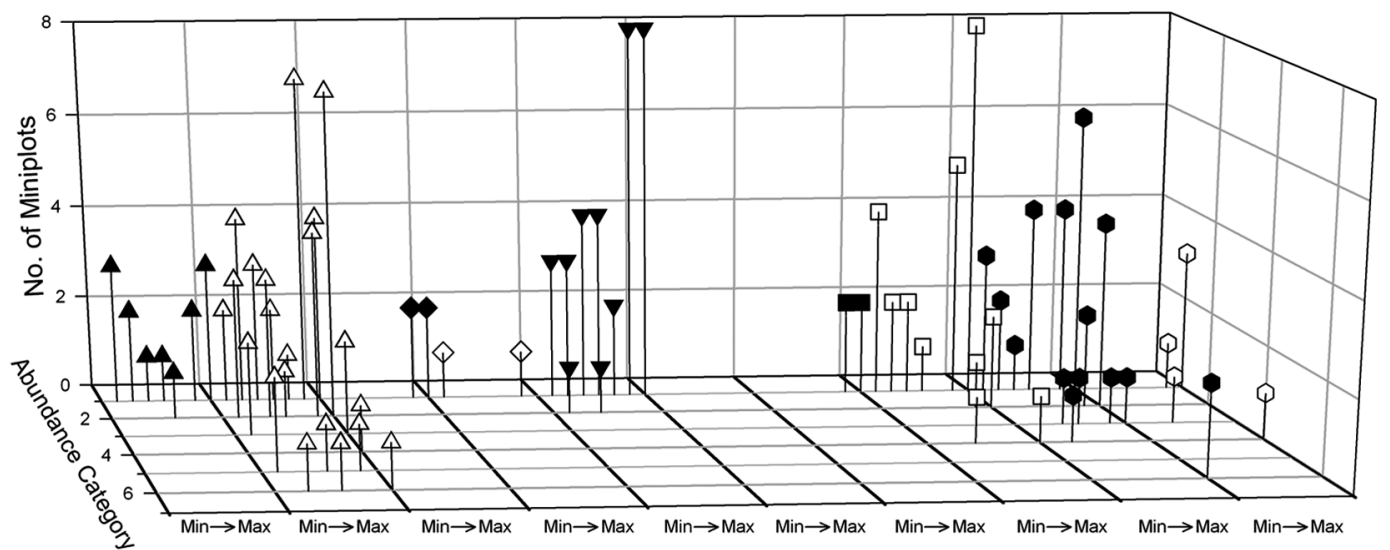

Distance from Edge Category

$$
\begin{array}{ll}
\Delta & \text { Cananga odorata } \\
\triangle & \text { Dysoxylum spp. } \\
& \text { Elaeocarpus ulianus } \\
\diamond & \text { Macaranga harveyana } \\
\nabla & \text { Myristica inutilis } \\
\nabla & \text { Pipturus argenteus } \\
\square & \text { Pisonia umbellifera } \\
\square & \text { Planchonella samoensis } \\
& \text { Pometia pinnata } \\
& \text { Syzygium samarangense }
\end{array}
$$

\section{B. SAPLINGS}

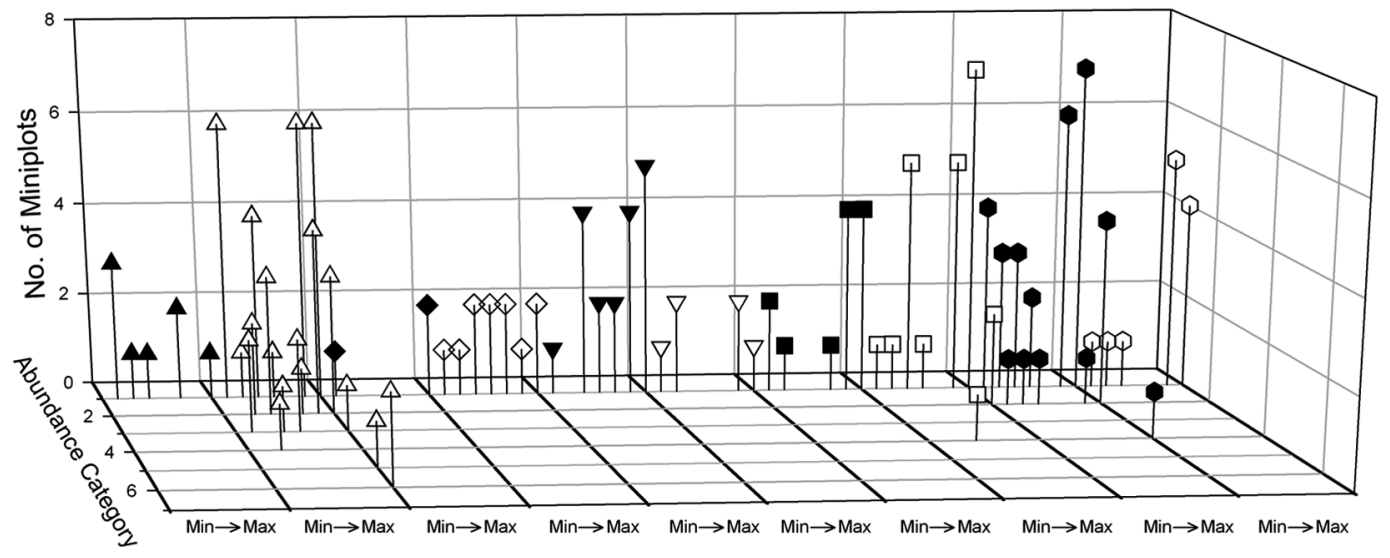

Distance from Edge Category

FIGURE 4. Spatial grouping and distance from edge of seedlings (A) and saplings (B) from 10 tree species in the Ottoville Lowland Forest, and the number of $25-\mathrm{m}^{2}$ miniplots in which they occurred. "Abundance Category" indicates spatial clumping in six categories from 1 (one to five individuals per miniplot) to 6 ( $>25$ individuals per miniplot). "Distance from Edge Category" indicates distance from the forest edge in seven categories from Min $(\leq 10 \mathrm{~m})$ to $\operatorname{Max}(>100 \mathrm{~m})$. 
slopes. Indeed, of 41 plots analyzed by Amerson et al. (1982b), Pometia pinnata occurred in only three: one on $\mathrm{Ta}^{\text {'u }}$ Island, one in a heavily disturbed forest that has since been denuded, and one within $1 \mathrm{~km}$ of the OLF. Finally, Tafuna is highly disturbed, with substantial loss of forest cover since the 1960s (American Samoa Government, unpubl. aerial and satellite images). There are no other patches of native lava flow forest in Tafuna that even approach the size of the OLF (pers. obs.), in spite of the small size of the OLF itself. For these reasons, we are confident that this patch represents a true remnant and that similar areas of its size are not present elsewhere on Tutuila. Thus, the low replaceability of the OLF argues that it warrants a high conservation priority.

Our analyses also suggest that the OLF can persist as a functional and unique forest if it is protected from human disturbance. $\mathrm{Al}-$ though a large number of natural factors can affect persistence of plant populations in habitat fragments (Laurance and Bierregaard 1997), we were most concerned that direct threats to adult survival (e.g., hurricanes and diseases) and indirect threats to recruitment (e.g., edge effects) would reduce the conservation value of the OLF even if protective measures were instituted.

To predict the vulnerability of the OLF to hurricanes and diseases we tested the spatial patterns of trees and recruits. Our main assumption was that aggregations (i.e., clumping within a species) increase vulnerability of a species to spatially discrete disturbances such as hurricanes. However, spatial aggregation may be beneficial if it reduces betweengroup transmission of pathogens such as Phellinus noxius (Swinton and Anderson 1995). We found significant clumping among adult trees at several spatial scales, both within several characteristic species (including Dysoxylum maota, Dysoxylum samoense, Elaeocarpus ulianus, and Pometia pinnata) and when we tested all species together. At the smallest spatial scale, however, neither the tree community as a whole nor any species except $P$. pinnata exhibited significant clustering.

These statistics seem to warrant concern, but we feel that the overall structure of the OLF is likely to be robust to spatially discrete threats. First, the majority of dominant tree adults either are randomly distributed (22 of 40 cases we tested) or are widespread and occur in high abundances (10 of 18 of the significantly clumped cases). High abundances presumably provide a buffer against mortality caused by hurricanes, which are unlikely to cause greater than $60 \%$ mortality (Elmqvist et al. 1994). Second, the persistence of adult trees in the OLF after hurricanes Ofa (1990) and Val (1991) suggests that these species have substantial hurricane resistance (Whistler 1993). Third, at the most local scale the entire tree community was significantly overdispersed (regularly distributed). This could ameliorate the impact of generalist pathogens such as Phellinus noxius (Brooks 2002) on any one tree species.

Nevertheless, there remains cause for concern in three cases. First, the local clustering of Pometia pinnata may increase the risk to this species from specialist pathogens or herbivores (but cf. Lieberman and Lieberman 1994). Second, the randomly distributed but relatively uncommon Syzygium samarangense may be at generally increased risk of local extinction (Boughton and Malvadkar 2002). Third, Elaeocarpus ulianus has high vulnerability within the OLF, because adults are significantly clumped at two spatial scales and occur in relatively low abundances. Any plan to preserve the OLF should perforce include a focused risk assessment of these three species.

Indirect threats such as isolation and edge effects may also affect the viability of tree populations in forest fragments. To test this possibility we examined the abundances and spatial distributions of seedlings and saplings (i.e., recruits). We assumed that overall recruit abundances were indicators of two factors important to population viability: (1) the productivity of the mature trees in the OLF and (2) the suitability of the substrate for seed set.

It is possible that seeds could have been transported to the OLF from other sites. All tree species occur elsewhere on Tutuila, and 
all have fruits that can be dispersed by volant vertebrates. However, transfer from outside the OLF is unlikely to be the case for the majority of recruits, especially for those species with abundant seedlings. First, long-distance dispersal is expected to be a relatively rare phenomenon (Willson and Traveset 2000). Second, recruit abundances will not necessarily correspond with abundances of adults (Harrington et al. 1997), especially if recruitment is occurring from outside the forest. We found, however, a strong positive correlation between abundances of seedlings, saplings, and adults across all tree species.

The life-stage structure of the dominant species in the OLF suggests healthy populations of most species. There is an approximately linear decline in the frequencies between seedling, sapling, and adult stages, except in two gap-colonizing species (Macaranga harveyana and Pipturus argenteus) and in Pisonia umbellifera, which occurs widely but in low numbers in undisturbed forests (Amerson et al. 1982b). In P. umbellifera recent recruitment may have been, or may be becoming, limited, a situation that warrants further study.

The spatial distributions of seedlings and saplings show potential edge effects in two of the dominant tree species: Elaeocarpus ulianus and Pisonia umbellifera. In those two species we found no seedlings within $50 \mathrm{~m}$ of an edge of the OLF. However, both species occur in relatively low abundances and both have saplings in close proximity to edges. Because our data are from random samples, systematic or focal sampling of these species would be prudent when considering conservation measures for the OLF. Nevertheless, our results suggest potential edge effects in $20 \%$ of the dominant species, in spite of the apparent overall health of the OLF. These data argue against any incursions that might increase the proportion of edge.

Spatial clustering of recruits is primarily a concern in species with relatively few individuals or if recruits are exclusively found in groups. Because this was not the case in the OLF, there appears to be little risk that a spatially discrete disturbance such as a hurricane would dramatically alter recruitment patterns in the forest. However, such disturbances might potentially have substantial impacts on species that have very low abundances of recruits (i.e., E. ulianus and P. umbellifera) regardless of their dispersion in space.

\section{CONCLUSIONS}

Our results show that in spite of its small size and relative isolation, the OLF has a considerable value for conservation. It contains a substantially unique flora. The dominant tree species generally appear capable of long-term viability. However, the data also suggest an inherent fragility, with low recruit abundances and possible edge effects in at least two of the dominant species.

Tree species may also exhibit deleterious effects of fragmentation over long time scales (Ledig 1986, Brook et al. 2002). Our analyses are based on the forest as it is currently constituted. We cannot predict with certainty the performance of the tree species therein over the long term or if the fragmentation of the forest were to increase. However, our findings argue that small remnant patches of habitat may indeed be worth conserving, especially in tropical island ecosystems such as American Samoa that have generalist, volant dispersers and pollinators.

\section{ACKNOWLEDGMENTS}

Integral members of the field crew were S. Fa'aumu, D. Meredith, and A. Tualaulelei (of DMWR) and K. Fa'atamala, R. Lotovale, and T. Magalei (of American Samoa Community College-Land Grant). D. E. Hanson, E. L. Webb, and three anonymous reviewers made constructive comments on the manuscript.

\section{Literature Cited}

Amerson, A. B., Jr., W. A. Whistler, and T. D. Schwaner. 1982a. Wildlife and wildlife habitat of American Samoa. I. Environment and ecology. Fish and Wildlife Service, U.S. Department of the Interior, Washington, D.C. . 1982b. Wildlife and wildlife habitat 
of American Samoa. II. Accounts of flora and fauna. Fish and Wildlife Service, U.S. Department of the Interior, Washington, D.C.

Benítez-Malvido, J., and M. Martínez-Ramos. 2003. Impact of forest fragmentation on understory plant species richness in Amazonia. Conserv. Biol. 17:389-400.

Boughton, D., and U. Malvadkar. 2002. Extinction risk in successional landscapes subject to catastrophic disturbances. Conserv. Ecol. 6:2, http://www.consecol.org/ vol6/iss2/art2.

Brook, B. W., D. W. Tonkyn, J. J. O'Grady, and R. Frankham. 2002. Contribution of inbreeding to extinction risk in threatened species. Conserv. Ecol. 6:16, http://www .consecol.org/vol6/iss1/art16.

Brooks, F. E. 2002. Brown root rot disease in American Samoa's tropical rain forests. Pac. Sci. 56:377-387.

Burkey, T. V. 1995. Extinction rates in archipelagoes: Implications for populations in fragmented habitats. Conserv. Biol. 9:527541 .

Dale, M. R. T. 1999. Spatial pattern analysis in plant ecology. Cambridge University Press, Cambridge, United Kingdom.

Elmqvist, T., W. E. Rainey, E. D. Pierson, and P. A. Cox. 1994. Effects of tropical cyclones Ofa and Val on the structure of a Samoan lowland rain forest. Biotropica 26:384-391.

Haase, P. 1995. Spatial pattern analysis in ecology based on Ripley's K-function: Introduction and methods of edge correction. J. Veg. Sci. 6:575-582.

Harrington, G. N., A. K. Irvine, F. H. J. Crome, and L. A. Moore. 1997. Regeneration of large-seeded trees in Australian rainforest fragments: A study of higher order interactions. Pages 292-303 in W. F. Laurance and R. O. Bierregaard Jr., eds. Tropical forest remnants: Ecology, management, and conservation of fragmented communities. University of Chicago Press, Chicago.

Krebs, C. J. 1999. Ecological methodology, 2nd ed. Benjamin Cummings, San Francisco.

Laurance, W. F., and R. O. Bierregaard Jr., eds. 1997. Tropical forest remnants: Ecology, management, and conservation of fragmented communities. University of Chicago Press, Chicago.

Ledig, F. T. 1986. Heterozygosity, heterosis, and fitness in outbreeding plants. Pages 77-104 in M. E. Soulé, ed. Conservation biology: The science of scarcity and diversity. Sinauer Associates, Sunderland, Massachusetts.

Leigh, E. G., Jr., S. J. Wright, E. A. Herre, and F. E. Putz. 1993. The decline of tree diversity on newly isolated tropical islands: A test of a null hypothesis and some implications. Evol. Ecol. 7:76-102.

Lieberman, M., and D. Lieberman. 1994. Patterns of density and dispersion of forest trees. Pages 106-119 in L. A. McDade, K. S. Bawa, H. A. Hespenheide, and G. S. Hartshorn, eds. La Selva: Ecology and natural history of a neotropical rain forest. University of Chicago Press, Chicago.

Lovejoy, T. E., R. O. Bierregaard, J. M. Rankin, and H. O. R. Schubart. 1983. Ecological dynamics of tropical forest fragments. Pages 377-384 in S. L. Sutton, T. C. Whitmore, and A. C. Chadwick, eds. Tropical rain forest: Ecology and management. Blackwell Scientific Publications, Oxford, United Kingdom.

Lovejoy, T. E., R. O. Bierregaard Jr., A. B. Rylands, J. R. Malcolm, C. E. Quintela, L. H. Harper, K. S. Brown Jr., A. H. Powell, G. V. N. Powell, H. O. R. Schubart, and M. B. Hays. 1986. Edge and other effects of isolation on Amazon forest fragments. Pages 257-285 in M. E. Soulé, ed. Conservation biology: The science of scarcity and diversity. Sinauer Associates, Sunderland, Massachusetts.

Mangel, M., and C. Tier. 1994. Four facts every conservation biologist should know about persistence. Ecology 75:607-614.

Mueller-Dombois, D., and F. R. Fosberg. 1998. Vegetation of the tropical Pacific islands. Springer-Verlag, New York.

Rudd, H., J. Vala, and V. Schaefer. 2002. Importance of backyard habitat in a comprehensive biodiversity conservation strategy: A connectivity analysis of urban green spaces. Restor. Ecol. 10:368-375. 
Swinton, J., and R. M. Anderson. 1995. Model frameworks for plant-pathogen interactions. Pages 280-294 in B. T. Grenfell and A. P. Dobson, eds. Ecology of infectious diseases in natural populations. Cambridge University Press, Cambridge, United Kingdom.

Teo, D. H. L., H. T. W. Tan, R. T. Corlett, C. M. Wong, and S. K. Y. Lum. 2003. Continental rain forest fragments in Singapore resist invasion by exotic plants. J. Biogeogr. 30:305-310.

Trail, P. W. 1993. Zoological survey of the Ottoville Lowland Forest. Department of Marine and Wildlife Resources Technical Report, Government of American Samoa, Pago Pago.

Turner, I. M., and R. T. Corlett. 1996. The conservation value of small, isolated fragments of lowland tropical rain forest. Trends Ecol. Evol. 11:330-333.

Webb, E. L., and S. Fa'aumu. 1999. Diversity and structure of tropical rain forest of Tutuila, American Samoa: Effects of site age and substrate. Plant Ecol. 144:257274.

Webb, E. L., B. J. Stanfield, and M. L. Jensen. 1999. Effects of topography on rainforest tree community structure and diversity in American Samoa, and implications for frugivore and nectarivore populations. J. Biogeogr. 26:887-897.

Whistler, W. A. 1980. The vegetation of eastern Samoa. Allertonia 2:45-190.

1993. Botanical survey of the Ottoville Lowland Forest, Tafuna, Tutuila, American Samoa. Department of Marine and Wildlife Resources Technical Report, Government of American Samoa, Pago Pago.

. 2002. The Samoan rainforest. Isle Botanica, Honolulu, Hawai'i.

Willson, M. F., and A. Traveset. 2000. The ecology of seed dispersal. Pages 85-110 in M. Fenner, ed. The ecology of regeneration in plant communities. CABI Publications, Wallingford, United Kingdom. 